\title{
IL-6 Directed Therapy in Transplantation
}

\author{
Cynthia L. Miller ${ }^{1} \cdot$ Joren C. Madsen ${ }^{1,2}$ (I)
}

Accepted: 22 May 2021 / Published online: 3 June 2021

(C) The Author(s), under exclusive licence to Springer Nature Switzerland AG 2021

\begin{abstract}
Purpose of Review IL-6 is a pleiotropic, pro-inflammatory cytokine that plays an integral role in the development of acute and chronic rejection after solid organ transplantation. This article reviews the experimental evidence and current clinical application of IL-6/IL-6 receptor (IL-6R) signaling inhibition for the prevention and treatment of allograft injury.

Recent Findings There exists a robust body of evidence linking IL- 6 to allograft injury mediated by acute inflammation, adaptive cellular/humoral responses, innate immunity, and fibrosis. IL-6 promotes the acute phase reaction, induces B cell maturation/ antibody formation, directs cytotoxic T-cell differentiation, and inhibits regulatory T-cell development. Importantly, blockade of the IL-6/IL-6R signaling pathway has been shown to mitigate its harmful effects in experimental studies, particularly in models of kidney and heart transplant rejection. Currently, available agents for IL-6 signaling inhibition include monoclonal antibodies against IL-6 or IL-6R and janus kinase inhibitors. Recent clinical trials have investigated the use of tocilizumab, an anti-IL-6R $\mathrm{mAb}$, for desensitization and treatment of antibody-mediated rejection (AMR) in kidney transplant recipients, with promising initial results. Further studies are underway investigating the use of alternative agents including clazakizumab, an anti-IL-6 mAb, and application of IL-6 signaling blockade to clinical cardiac transplantation.

Summary IL-6/IL-6R signaling inhibition provides a novel therapeutic option for the prevention and treatment of allograft injury. To date, evidence from clinical trials supports the use of IL- 6 blockade for desensitization and treatment of AMR in kidney transplant recipients. Ongoing and future clinical trials will further elucidate the role of IL-6 signaling inhibition in other types of solid organ transplantation.
\end{abstract}

Keywords Transplantation $\cdot$ Allografts $\cdot$ Interleukin- $6 \cdot$ Rejection $\cdot$ Tocilizumab $\cdot$ Clazakizumab

\section{IL-6: A Pleiotropic Cytokine}

Cytokines have been identified as key components of immune regulation and tissue homeostasis, and disruptions in cytokine activation pathways result in autoimmunity and tissue injury [1-3]. IL-6 is a pleiotropic cytokine that has been shown to cause deleterious inflammatory, immune, and fibrogenic responses. It was discovered by Kishimoto et al. in 1986 and identified as B-cell stimulating factor 2 (BSF-2) for its role in promoting immunoglobulin synthesis by activated $\mathrm{B}$ cells

This article is part of the Topical Collection on Immunology

Joren C. Madsen

jcmadsen@mgh.harvard.edu

1 Center for Transplantation Sciences, Massachusetts General Hospital, Boston, MA, USA

2 Division of Cardiac Surgery, Department of Surgery, Massachusetts General Hospital, White 510, 55 Fruit Street, Boston, MA 02114, USA
[4-6]. IL-6 has since emerged as a master regulator of immune and physiologic processes involving multiple organ and cellular systems, including the acute phase reaction, innate and adaptive immunity, hematopoiesis, apoptosis, and cellular metabolism $[1,7,8]$.

During physiologic inflammatory responses, IL-6 triggers the synthesis of acute phase proteins and facilitates the development of specific immunity. It modulates the activation, proliferation, and differentiation of $\mathrm{T}$ - and B-cells and induces cells of monocyte, endothelial, and stromal lineages to acquire a pro-inflammatory phenotype. Unlike the majority of other cytokines which have restricted cellular expression and signaling, IL- 6 can be produced by most stromal and immune cells in the human body. These include a wide range of immune and non-immune cells, including $\mathrm{T}$ and $\mathrm{B}$ lymphocytes, monocytes, fibroblasts, endothelial cells, adipocytes, and smooth muscle cells $[9,10]$. Under physiologic conditions, the level of IL-6 in peripheral blood/plasma is 0-6 pg/mL [7] with dramatic elevations after IL-6 activation/transcription; IL-6 levels in the microgram/ 
milliliter range have been shown to correlate with increased risk of mortality [7, 11].

IL-6 production is induced in infection, cancer, and nearly all inflammatory conditions [2, 12]. Dysregulated IL-6 signaling has been implicated in autoimmunity (rheumatoid arthritis, Castleman's syndrome), chronic immune disorders (GVHD), cardiovascular disease, diabetes mellitus, neuroendocrine disorders, and tumorigenesis [1, 7, 13-15]. As such, IL-6 has become a key target for clinical intervention in a multitude of disease processes, including immune-mediated allograft injury. Here, we review the experimental evidence and current clinical application of IL-6/IL-6R signaling inhibition for the prevention and treatment of allograft injury after solid organ transplantation.

\section{Diverse IL-6 Signaling Pathways}

IL-6 consists of 184 amino acids in addition to a 28 amino acid signal peptide [16]. It utilizes unique signaling mechanisms including classical, trans-signaling, and trans-presentation pathways $[8,17,18]$. The IL-6 receptor (IL-6R) forms a complex of molecules consisting of gp 80 and gp130 components; the gp80 subunit directly binds to IL- 6 and is generally identified as IL-6R and relies on the gp130 component for signal transduction. Notably, there exist two forms of IL-6R (gp80): a membrane-bound transmembrane protein and a soluble sIL$6 \mathrm{R}$ protein $[1,11]$. The binding of IL- 6 to gp80 causes gp130 on the cell surface to homodimerize, resulting in a formation of a functional IL-6/IL-6R/gp130 complex and activation of downstream signal transduction pathways leading to janus kinase (JAK)-dependent STAT3 signaling (as well as $\mathrm{PI} 3 \mathrm{~K} / \mathrm{AKT}$ and RAS/MAPK pathways) [19]. The predominant target of IL-6 signaling is STAT3, which regulates genes involved in cellular proliferation (cyclin B1, cyclin D1), survival (B cells), angiogenesis (vascular endothelial growth factor), fibrosis, and immunosuppression (IL-10) [20-22].

The classical pathway (cis-signaling) occurs when IL-6 binds the membrane-bound heterodimer of the IL-6R and gp130 to activate downstream JAKs. The membrane-bound IL-6R is expressed on a small subset of cells including leukocytes, megakaryocytes, and hepatocytes, which enables the classical signaling pathway to regulate acute phase inflammation, hematopoiesis, and immune cell proliferation/ differentiation [16].

Trans-signaling utilizes a soluble form of IL-6R (sIL-6R), which is produced by alternative gene splicing of IL-6R mRNA and cleavage by ADAM10 and ADAM17 from cell membranes. In this pathway, IL-6 binds sIL-6R in the extracellular space, and the complex then binds gp130 on any cell membrane to activate downstream signaling as in cissignaling [23-26]. Trans-signaling dramatically expands the activation capacities and pathological effects of IL-6 by enabling the transmission of IL-6R-initiated signals to cells that do not constitutively express the receptor. Indeed, sIL$6 \mathrm{R}$ and the widespread expression of gp130 enable IL-6 to activate nearly every cell in the body $[27,28]$. Trans-signaling is regulated by a soluble form of gp130 (sgp130), which forms a complex with IL-6/sIL-6R and prevents its binding to membrane-bound gp130 [29].

Trans-presentation is a more recently identified IL-6 signaling pathway that occurs in the context of dendritic cells presenting to naïve CD4+ T-cells [30••]. IL-6 and IL-6R expressed in the cytoplasm of dendritic cells combine and are transported to the plasma membrane. There, the IL-6/IL6R complex interacts with gp130 molecules expressed by CD4+ T cells, resulting in activation of JAK/STAT3 signaling and commitment of the T-cell to a tissue-destructive, pathogenic phenotype. Trans-presentation was discovered in mice and has not yet been confirmed in humans [2, 30••].

The diverse mechanisms of IL- 6 signaling and ubiquitous ability of IL-6 to stimulate nearly every cell type provide a unique opportunity for therapeutic intervention in human disease, including the inflammatory and immune processes associated with solid organ transplant rejection.

\section{Integral Role of IL-6 in Inflammation/Immunity}

IL-6/IL-6R signaling activates pathways involved in inflammation and ischemia reperfusion injury (IRI), adaptive cellular and humoral immunity, innate immunity, and fibrosis, all of which contribute to its role in promoting allograft injury.

\section{Inflammation}

The deleterious impacts of IL- 6 begin prior to organ procurement, with the promotion of a proinflammatory state due to IL-6 upregulation in the setting of brain death [31]. Following transplantation, IRI resulting from the use of cold, static preservation leads to further increases in intragraft IL-6 levels [32-34]. Elevated IL-6 in turn increases the level of adhesion molecules, inflammatory cytokines (IL-17, IFN- $\gamma$ ), and molecules that regulate migration, such as monocyte chemoattractant protein-1 (MCP-1) in endothelial cell [35]. Importantly, blocking IL-6 has been shown to mitigate the pro-inflammatory milieu associated with brain death and IRI [36-38].

\section{Adaptive Cellular Immunity}

The involvement of IL-6 in adaptive cellular immunity results from its ability to expand the CD8+ T cell population and promote differentiation of naïve $\mathrm{CD} 4+\mathrm{T}$ cells away from regulatory phenotypes. By augmenting the expression of IL2 and receptor CD122/CD25, IL-6 expands the effector/ 
memory $\mathrm{CD}^{+}$T cell population [39]. IL-6, along with TGF $\beta$, is essential for the differentiation of naïve CD4+ T cells towards the deleterious Th17 effector phenotype. The IL-17 produced by Th17 cells is responsible for neutrophil proliferation and migration, endothelial cell activation, and fibroblast activation and proliferation, all of which participate in the potent cytopathic responses implicated in acute and chronic allograft rejection [40, 41]. IL-17 also stimulates monocytes/ macrophages, among other cell types (e.g., endothelium), to produce pro-inflammatory cytokines including IL-6 itself, thereby creating a positive feedback loop [42]. Blockade of this IL-6/IL-17 amplification circle is one purported mechanism by which IL-6 signaling inhibition exerts its beneficial effects [43-45]. Indeed, RNA profiling suggests that the IL-6 pathway is a promising target for preventing acute cellular rejection [46]. Moreover, since Th17 and regulatory T cells (Tregs; CD4+, CD25+, FoxP3+) share a reciprocal developmental origin, IL-6 inhibits TGF $\beta$-induced Treg development [40]. IL-6 blockade thereby promotes Treg generation, which counterbalances the effects of alloreactive Th1 and Th17 lymphocytes [47]. IL-6R blockade has been shown to promote the development of CD39 ${ }^{+}$Tregs in rheumatoid arthritis [48] and neutralize IL-6-induced arterial allograft rejection by promoting the emergence of Tregs [49]. This is of particular significance given the accumulating evidence suggesting that Foxp $3^{+}$Tregs are critical for maintaining immune homeostasis and immune tolerance in transplantation [50, 51]. Lastly, amplification and expansion of the allogeneic $\mathrm{T}$-cell response by graft-derived IL-6 have been shown to contribute to vascular rejection and allograft arteriosclerosis [52].

\section{Humoral Immunity}

Development of humoral immunity requires IL-6, in conjunction with other cytokines, for normal antibody production [6]. Indeed, IL-6 is critical for the induction of follicular Th (Tfh) cells as well as the production of IL-21, which regulates immunoglobulin synthesis $[53,54]$. IL-6 is also crucial for B cell differentiation into plasmablasts and for enhancing plasmablast survival following differentiation $[55,56]$. Thus, it is not surprising that blocking IL-6 signaling effectively reduces $\mathrm{B}$ cell activation, plasmablast differentiation, and antibody production (both primary and recall) [57-59••].

\section{Innate Immunity/Fibrosis}

Innate immune signals via toll-like receptors (TLR), IL-1, or tumor necrosis factor (TNF) receptors can induce IL-6 in a variety of epithelial and endothelial cell types [60]. NK cells express the IL-6R and can be activated by IL- 6 to induce cytotoxicity to endothelial cells in both mice and humans [61]. IL-6 appears to play an important role in activating NK cells in long-term cardiac allografts, as IL-6 deficiency in mouse hearts has been shown to prevent NK-mediated cardiac allograft vasculopathy (CAV) [61]. IL-6 promotes collagen synthesis in fibroblasts, promotes their differentiation into myofibroblasts, and participates in vascular smooth muscle cell and endothelial cell proliferation/activation [10], all of which result in chronic allograft injury via fibrosis.

In summary, by altering upstream differentiation of alloreactive lymphocytes [43, 44, 47, 62], promoting the generation of Tregs [63], blocking immunoglobulin synthesis, and deamplifying downstream aspects of the inflammatory cascade [64], IL-6/IL-6R signaling inhibition provides a novel therapeutic option in preventing IRI, abrogating acute cellular rejection (ACR) and antibody-mediated rejection (AMR) and preventing fibrosis implicated in chronic allograft injury.

\section{IL-6 as a Critical Mediator of Allograft Injury}

There are now considerable data from experimental and human studies linking IL-6 to allograft injury. Importantly, blockade of the IL-6/IL-6R signaling pathway has been shown to abrogate these effects. In a mouse skin transplantation model, IL- 6 promoted T cell alloreactivity and impaired the ability of Tregs to suppress effector T cell alloresponses [65]. Inhibition of IL-6 signaling with anti-IL6R mAb attenuated de novo donor-specific antibody (DSA) production and alloantibody recall responses by modulating immune regulatory and effector cells $[57,66]$. In murine models of solid organ transplantation, there are substantial and convincing data from many groups demonstrating that IL-6 plays a critical role in the pathogenesis of acute and chronic allograft rejection; moreover, blocking IL-6 reduces/prevents ACR, AMR, and effectively diminishes fibrosis [49, 57, 61, 67-79]. Studies in human recipients of different organ allografts consistently show that higher levels of IL-6 (gene and protein levels) are associated with worse outcomes (i.e., higher risk for acute rejection) [80-86]. Below, we review findings from important experimental and human studies on the role of IL-6 in kidney, liver, cardiac, and lung transplantation.

\section{Kidney Transplantation}

The role of IL-6 in promoting acute and chronic kidney allograft rejection is well-established. In a murine model of kidney transplantation, renal expression of IL-6 was upregulated with decreased intragraft Foxp $3^{+}$Tregs following allograft rejection [87]. Moreover, lack of graft-produced IL-6 prolonged renal allograft survival and was associated with decreased circulating anti-graft alloantibodies and increased intragraft Tregs, suggesting that IL-6 signaling inhibition may prevent both humoral and cellular rejection [76]. In an experimental model of chronic allograft nephropathy, interstitial fibrosis/tubular atrophy was shown to be mediated by 
intragraft B-cell secretion of chemokines and cytokines, including IL-6 [88]. B-cell depletion resulted in decreased intragraft B cells, chemokines, and IL-6 levels as well as diminished allograft interstitial fibrosis and tubular atrophy, suggesting a potential role for IL-6 in mediating chronic allograft nephropathy.

In human renal transplant recipients, elevations of IL-6 in serum, urine, and biopsy tissue are observed during renal allograft rejection $[89,90]$, and levels correlate with the degree of inflammatory cell infiltration [36, 37]. Among renal allograft recipients undergoing tolerance induction using a mixed chimerism strategy, those who developed high serum IL-6 and IL-17 levels experienced rejection, while recipients without high IL-6/IL-17 survived long-term without rejection [91].

\section{Liver Transplantation}

IL-6 is a key factor in promoting hepatocyte regeneration and maintaining liver homeostasis [92-94]; however, the role of IL-6 in liver transplantation is less clear. Data from a number of clinical and preclinical studies implicate IL-6 in acute liver rejection [95-99]. However, some rodent studies suggest that administration of IL-6 may provide hepatoprotective effects in the setting of transplantation [100, 101]. Higher levels of IL-6 are observed in human liver transplant recipients undergoing rejection as compared to recipients without rejection $[95,97]$. In a nonhuman primate study evaluating serum IL-6 levels after orthotopic liver transplantation, animals who developed acute rejection experienced significantly increased IL-6 levels at 3-4 days post-transplant, which preceded biochemical abnormalities by 2-3 days [98]. Additional studies of IL-6 gene polymorphisms have been shown to be predictive of acute rejection following clinical liver transplantation [96, 99], with the high IL-6 producer genotype representing a risk factor for the development of acute rejection [99]. In contrast, in-vitro IL-6 treatment of steatotic liver allografts significantly reduced post-transplant mortality and protected against primary nonfunction after liver transplantation in a murine model [101]. Another rodent study showed that pretreatment of recipient rats with IL-6 in vivo 24 and $12 \mathrm{~h}$ before surgery promoted donor liver regeneration and improved the survival rate after partial liver transplantation [100].

\section{Heart Transplantation}

Studies have consistently linked IL-6 with acute cardiac rejection. IL-6-deficient grafts survived approximately three times longer than wild-type controls, and graft-produced IL-6 promoted the activation of peripheral $\mathrm{CD}^{+}$and $\mathrm{CD}^{+} \mathrm{T}$-cells in a mouse model [67]. Zhao et al. demonstrated that IL-6 and IFN gamma were the major cytokines upregulated during cardiac allograft rejection in mice and that the combination of costimulatory blockade with systemic absence of IL-6 leads to tolerance by limiting effector T-cells and promoting Tregs [72]. In another study, neutralization of IL-6 in CD-8+ celldominant graft rejection delayed the onset of ACR and reduced graft T-cell infiltrates; in CD-4+ cell-mediated rejection, IL-6 neutralization prolonged graft survival, reduced serum DSA levels, and was associated with decreased graft infiltrate and altered Th1 responses [71]. The combination of these findings has established IL- 6 as a critical mediator of both cellular and antibody-mediated rejection in cardiac transplantation. In human heart transplant recipients, myocardial biopsies and serum samples demonstrate increased transcription of IL-6 mRNA and IL-6 levels during acute rejection, which correlate with the severity of histologic cardiac allograft rejection [82, 83, 102-104].

It is now well-established that IL-6 plays an important role in chronic cardiac allograft rejection manifested as graft fibrosis, cardiomyocyte hypertrophy, and CAV [49, 69, 70, 75]. Neutralization of IL-6 in murine heart transplant recipients resulted in decreased cardiomyocyte hypertrophy and lessened cardiac allograft fibrosis [70]. In a human arterial allograft model, IL-6 signaling inhibition attenuated chronic rejection in the form of CAV via emergence of Tregs [49]. By studying IL-6 levels in human coronary artery segments grafted into immunodeficient mice, the authors concluded that IL-6 released from injured allograft vessels (specifically, endothelial cells) inhibited an increase in CD161+ Tregs, ultimately resulting in augmented T-cell infiltration and vasculopathy [49]. IL-6, together with IL-17, has even been implicated in disruption of established allograft tolerance in response to TLR signals [105].

\section{Lung Transplantation}

Experimental murine and nonhuman primate models of lung transplantation have implicated IL-6 in both acute rejection and chronic lung allograft dysfunction (CLAD). Transplantation of incompatible lung allografts in rats resulted in elevated IL-6 mRNA levels in bronchoalveolar lavage (BAL) fluid of the transplanted lung on days one and six post-transplant, coinciding with histopathologic changes consistent with ACR [106]. Our group previously achieved longterm lung allograft tolerance for the first time in nonhuman primates by incorporating anti-IL-6R therapy (tocilizumab) in a mixed chimerism model [107]. In human lung transplant recipients, high levels of IL-6 and elevated IL-6/IL-10 ratios in donor's lungs were predictive of primary graft dysfunction and 30-day mortality $[84,108,109]$. In addition, IL-6 is upregulated in BAL fluid [85, 110], BAL-derived macrophages [111], and serum [86] of lung transplant recipients with ACR. Wheeler et al. demonstrated consistently elevated IL-6 and sIL-6R levels in BAL samples of human lung transplant recipients with CLAD and found that high BAL IL-6 levels were predictive of future CLAD development [68•]. They also 
demonstrated a $>50 \%$ reduction in allograft fibrosis in an IL-6 deficient murine orthotopic lung transplant model. The authors propose a synergistic relationship between infiltrating mononuclear cells and resident mesenchymal cells within the lung, which results in release of large quantities of IL-6 and sIL-6R and ultimately the development lung allograft fibrosis.

\section{Emerging Role of IL-6 Signaling Blockade in Clinical Transplantation}

\section{Current Agents}

Given the importance of IL-6 in mediating diverse inflammatory and immunomodulatory pathways, there exists a growing interest in the development of novel agents that interfere with dysfunctional IL-6/IL-6R signaling [2, 3]. These include agents that block the cytokine, its receptor, or intracellular kinases and transcription factors (Fig. 1). Agents that have been approved for clinical use or are in development include those that target IL-6 (clazakizumab, olokizumab, siltuximab, sirukumab), IL-6R (tocilizumab, sarilumab), the IL-6/sIL-6R complex (olamkicept), and downstream janus kinases (tofacitinib, baricitinib, ruxolitinib, filgotinib, upadacitinib) [2, 112]. Tocilizumab, a humanized monoclonal antibody against IL-6R, represents the first of these agents and was initially developed in 1997; it is currently approved in multiple countries for the treatment of rheumatoid arthritis, juvenile idiopathic arthritis, giant cell arteritis, Castleman disease, and cytokine release syndrome, with recent studies investigating its use in critically ill patients with COVID-19 [10, 16, 113, 114]. Application of IL-6/IL-6R signaling blockade in clinical transplantation has mainly focused on desensitization and prevention/treatment of antibody-mediated rejection in kidney transplant recipients, with the most-studied agents including tocilizumab and clazakizumab (Table 1).

\section{Tocilizumab}

Tocilizumab has shown efficacy in single-arm, pilot trials aimed at reducing HLA antibody in highly sensitized patients awaiting kidney transplantation and those with AMR. One of the earliest studies was a single-center, phase I/II open-label study (NCT01594424) conducted by Vo et al. in 2015, in which 10 HLA-sensitized patients with end-stage renal disease who had failed desensitization with IVIg + rituximab +/- plasma exchange were treated with IVIg and monthly tocilizumab for 6 months [59••]. Serious adverse events (SAEs) occurred in 4 patients, with 5 of 7 SAEs likely related to tocilizumab treatment. Five patients underwent transplantation at a mean of 8 months post-treatment and 25 months post-initial treatment for desensitization. Overall, tocilizumab therapy resulted in significantly reduced DSA levels, and there was no evidence of AMR on biopsies performed 6 months post-transplant. Importantly, when tocilizumab was discontinued, 2 patients developed mild AMR on biopsy at 1 year; the authors suggest that this may be due to rebound IL6/IL-6R signaling from accumulation of serum IL-6, resulting in reinvigoration of the alloimmune response.

A subsequent study by the same group evaluated tocilizumab as a "rescue" therapy for patients with DSApositive cAMR and transplant glomerulopathy who had previously failed standard of care treatment with IVIg + rituximab $+/-$ plasma exchange [115••]. Monthly tocilizumab treatment resulted in $80 \%$ graft survival at 6 years, significantly reduced DSA levels, and stabilized renal function without significant adverse events. Four of the 36 treated patients ultimately experienced graft loss due to cAMR; notably, all 4 patients had discontinued tocilizumab 6 months prior to graft loss for medical or financial reasons. This result further suggests that a rebound in IL-6/IL-6R signaling after cessation of tocilizumab may contribute to the initiation of alloimmune responses and ultimate allograft loss. More recently, tocilizumab has been investigated as a first-line therapy for cAMR in kidney transplantation. At a median follow up of 20 months, 15 patients treated for cAMR with monthly tocilizumab as the first line of therapy experienced stabilization of GFR and significant reduction in DSA, and biopsies at 6 months demonstrated improved pathology with reduced microvascular inflammation and no progression of transplant glomerulopathy, C4d deposition, or interstitial fibrosis/ tubular atrophy [116].

Findings from clinical trials support the use of tocilizumab for not only chronic but also acute AMR. Reduction in DSA and stabilization/improvement of renal function was observed in 7 kidney transplant recipients who received at least one dose of tocilizumab in addition to conventional therapies for acute AMR [117]. In contrast, a single-center observational study found that tocilizumab did not alter the course of AMR in 9 kidney transplant recipients when compared to historical controls, making it clear that a randomized trial is needed to clarify the role of IL-6 signaling inhibition in AMR [125•]. Notably, a study investigating infectious complications associated with the use of tocilizumab in kidney transplant recipients with DSA and/or AMR demonstrated lower rates of infection in tocilizumab-treated patients compared to those receiving IVIg/rituximab, with no infection-related deaths in either group [126].

IL-6 signaling blockade may also represent a potential treatment option for regulating the T-cell alloimmune response in kidney transplantation, based on findings from a recent randomized-controlled trial (NCT02108600) [118]. In this study, 30 kidney transplant recipients with subclinical graft inflammation identified on biopsy within 1 year posttransplant were randomized to standard triple-drug 


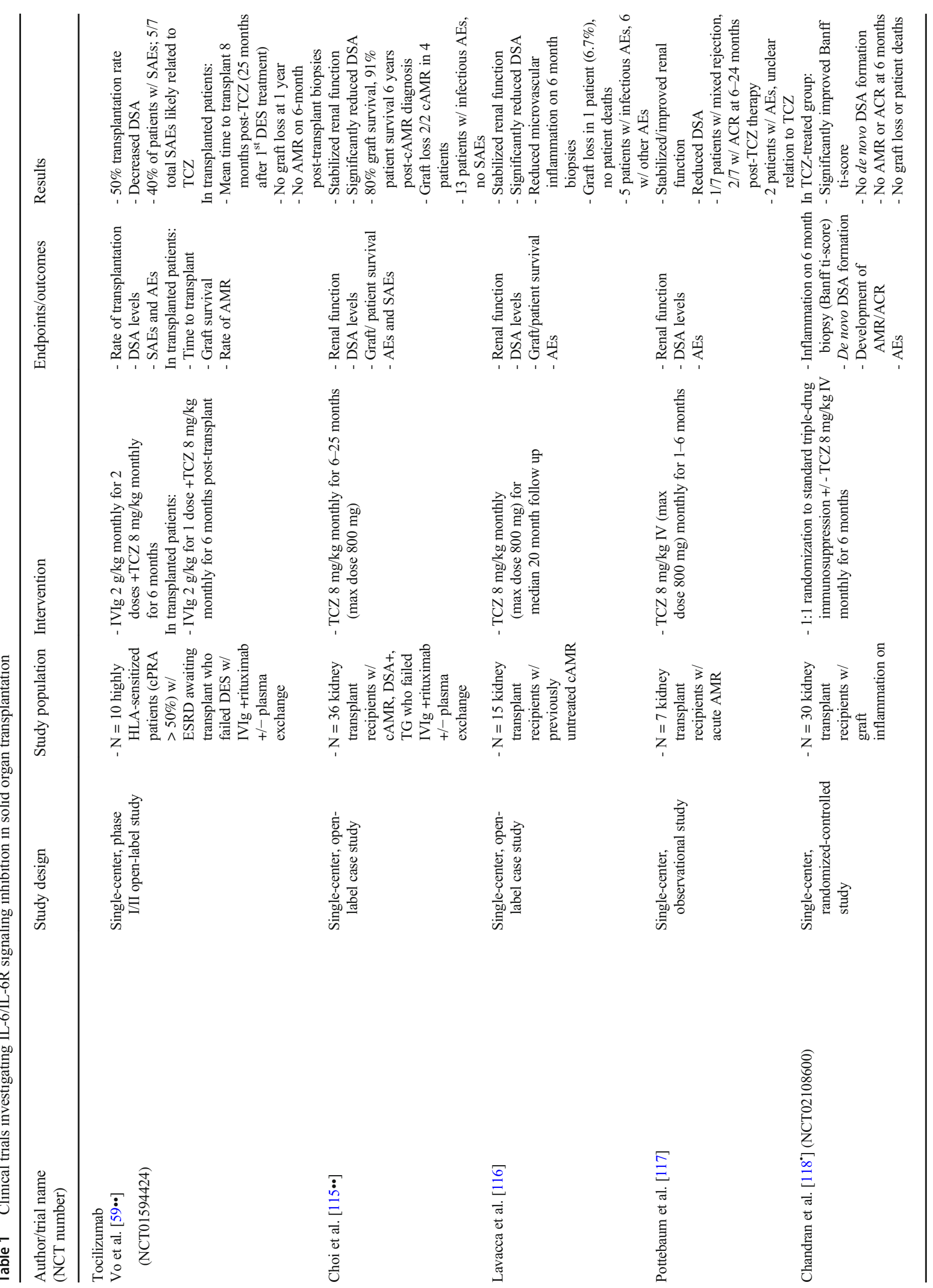




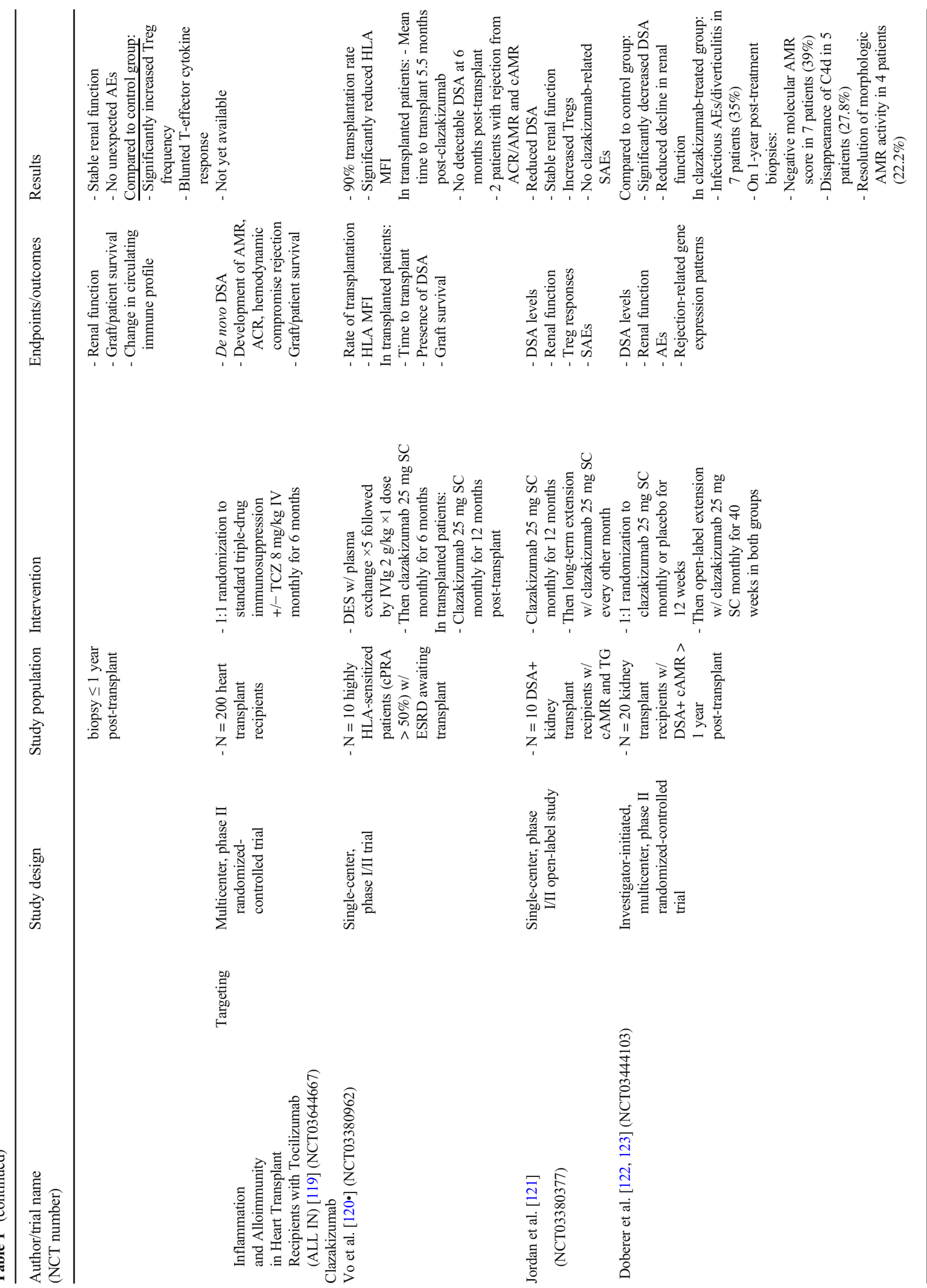


immunosuppression with or without 6 months of tocilizumab therapy. Compared to the control group, patients who received tocilizumab were found to have increased Treg frequency and a blunted Teff cytokine response, with no significant adverse effects related to tocilizumab therapy.

Based on experimental evidence supporting the crucial role of IL-6 in acute and chronic cardiac allograft rejection, a prospective, multicenter phase II clinical trial investigating the efficacy of tocilizumab in cardiac transplantation was initiated and is currently ongoing (NCT03644667; Targeting Inflammation and Alloimmunity in Heart Transplant Recipients with Tocilizumab (ALL IN)) [119]. In this NIAID/NIH-funded study, 200 heart transplant recipients are randomized to standard triple therapy maintenance immunosuppression with or without monthly tocilizumab for 6 months. Primary outcomes will be evaluated at 1 year post-transplant and defined by a composite endpoint including de novo DSA, biopsy-proven rejection (ACR, AMR), rejection resulting in hemodynamic compromise without biopsy/histologically-proven rejection, death, or re-transplantation.

\section{Clazakizumab}

More recent trials investigating IL-6 signaling inhibition in clinical transplantation have utilized clazakizumab, an antiIL-6 monoclonal antibody that has been evaluated extensively in RA but is not yet FDA approved [127 • ]. A potential benefit of direct IL-6 inhibition is the lack of posible rebound phenomenon resulting from the accumulation of serum IL-6. There are several ongoing studies evaluating the use of clazakizumab in highly sensitized patients awaiting transplantation and kidney transplant recipients with AMR. In a single-center, phase I/II trial (NCT03380962), highly HLA-sensitized patients received 6 doses of monthly clazakizumab therapy for desensitization with an additional 12 doses after transplantation [120 ]. Clazakizumab desensitization significantly reduced HLA mean fluorescence intensity (MFI), enabling transplantation in 9/10 patients with no detectable DSA at 6 months posttransplant. A sub-analysis of these patients revealed a marked increase in FoxP3+ Tregs at 180 days post-transplant, suggesting that anti-IL-6 therapy with clazakizumab promotes differentiation of CD4+ T-cells towards a Treg phenotype [128].

A single-center, phase I/II investigator-initiated study (NCT03380377) aims to evaluate the safety and tolerability of monthly clazakizumab administration in 10 DSApositive kidney transplant recipients with biopsy-proven cAMR and transplant glomerulopathy [121, 129]. At 18month follow-up, there were sustained reductions in mean DSA relative intensity scores, stabilization of renal function, and increased Tregs, without drug-related serious 

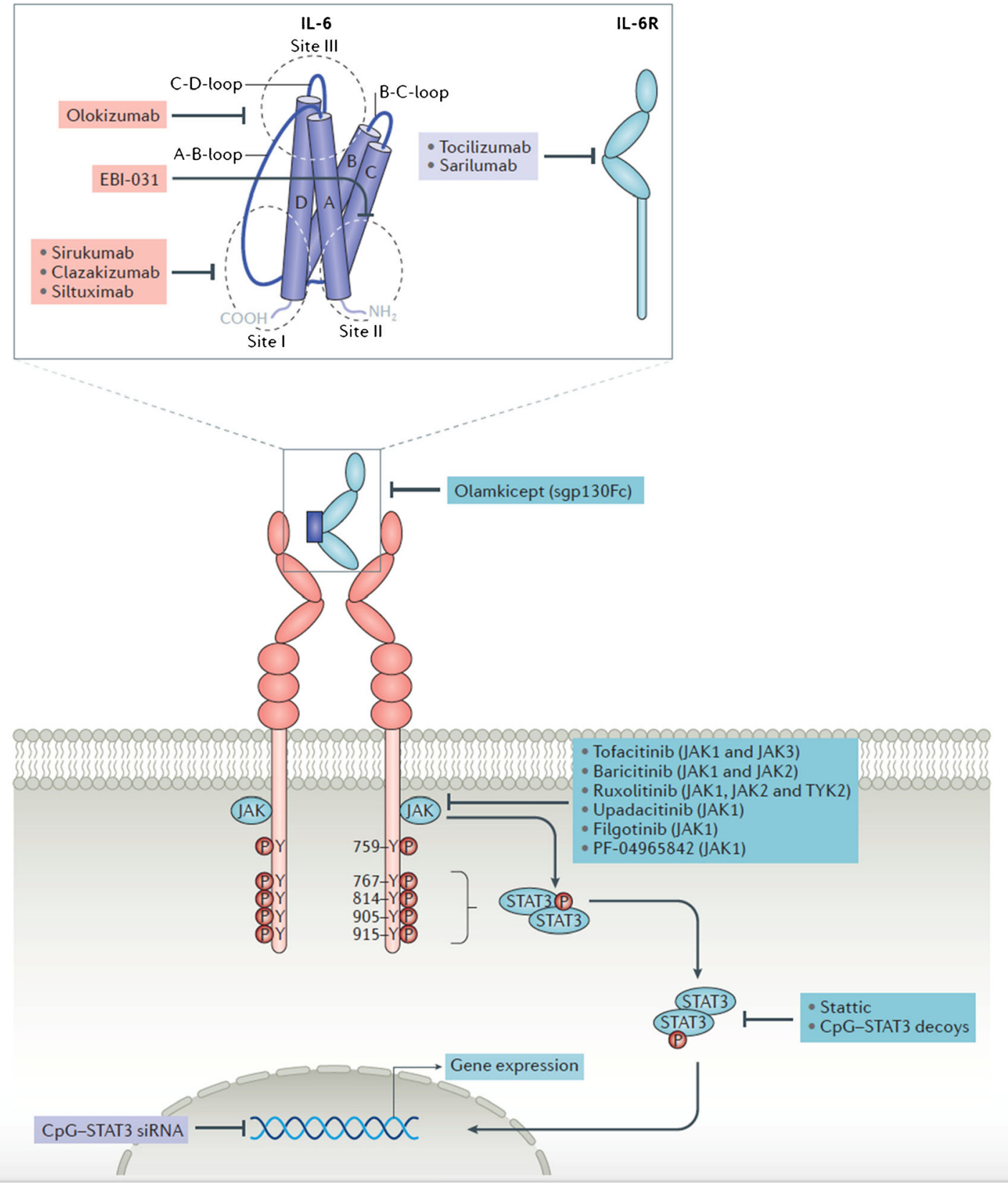

Fig. 1 Agents currently approved or in development for inhibition of IL-6/IL-6R signaling. Adapted from [2]

adverse events. A similar prospective, randomized-controlled study (NCT03444103) included 20 kidney transplant recipients $>1$ year post-transplant with DSA-positive cAMR randomized to 12 weeks of monthly clazakizumab or placebo, followed by a 40 -week open-lab extension in which all patients received clazakizumab [122]. Clazakizumab treatment was associated with a significant decrease in DSA and reduced decline in renal function [123]. Eighteen patients underwent renal allograft biopsy at 1 year, with negative molecular AMR score in seven (39\%), disappearance of C4d in five $(27.8 \%)$, and resolution of morphologic AMR activity in four patients $(22.2 \%)$. Seven patients developed infectious or diverticulitis-related complications leading to withdrawal from the trial. A secondary endpoint analysis found increased serum levels of total but not unbound IL-6 in clazakizumabtreated patients, arguing against a potentially harmful rebound phenomenon from the accumulation of unbound IL- 6 during treatment [130]. Currently, a large industry-sponsored, multicenter, randomized-controlled phase III trial (NCT03744910; Clazakizumab for the Treatment of Chronic Active AntibodyMediated Rejection in Kidney Transplant Recipients [IMAGINE]) is underway to clarify the safety and efficacy of clazakizumab in cAMR after kidney transplantation [124]. The study aims to recruit 350 patients and will assess 
the effect of up to 5 years of clazakizumab treatment on renal function and long-term graft survival.

\section{Future Directions/Conclusions}

There exists a convincing role for IL-6 in innate immune responses and adaptive immunity, including those associated with cellular and antibody-mediated rejection after solid organ transplantation. Preclinical studies suggest that IL-6/IL-6R signaling blockade may be effective in modifying the $\mathrm{T}$ - and B-cell responses to allografts, as well as deamplifying downstream aspects of the inflammatory cascade. Recent clinical trials in kidney transplantation have focused on the use of IL-6 signaling inhibition with antibodies against IL-6 or IL-6R for desensitization and for the treatment of acute and chronic AMR, with promising initial results. Ongoing and future clinical trials should investigate the application of IL-6 signaling blockade for the prevention of allograft injury in other types of solid organ transplantation, including cardiac and lung transplantation.

Acknowledgements The authors wish to thank Dr. Stanley C. Jordan for his critical review of the manuscript.

Funding This work was supported by NIH grants P01HL018646, P01AI123086, U01AI131470, and R25AI147393 and the Nina Starr Braunwald Research Fellowship Award from The Thoracic Surgery Foundation to CLM.

\section{Compliance with Ethical Standards}

Conflict of Interest The authors declare no competing interests.

Human and Animal Rights and Informed Consent All procedures performed in studies involving animals were in accordance with the ethical standards of the institution at which the studies were conducted.

\section{References}

Papers of particular interest, published recently, have been highlighted as:

- Of importance

-• Of major importance

1. Jordan SC, Choi J, Kim I, Wu G, Toyoda M, Shin B, et al. Interleukin-6, A cytokine critical to mediation of inflammation, autoimmunity and allograft rejection: therapeutic implications of IL-6 Receptor Blockade. Transplantation. 2017;101(1):32-44. https://doi.org/10.1097/TP.0000000000001452.

2. Garbers C, Heink S, Korn T, Rose-John S. Interleukin-6: designing specific therapeutics for a complex cytokine. Nat Rev Drug Discov. 2018;17(6):395-412. https://doi.org/10.1038/nrd.2018. 45.
3. Jordan SAN, Choi J, Huang E, Toyoda M, Kim I, Wu G, et al. Interleukin 6: pathogenic potential and therapeutic approaches in autoimmunity and transplant rejection. Encyclopedia of Life Sciences (eLS). Chichester: John Wiley \& Sons, Ltd.; 2018.

4. Kishimoto T, Hibi M, Murakami M, Narazaki M, Saito M, Taga T. The molecular biology of interleukin 6 and its receptor. CIBA Found Symp. 1992;167:5-16; discussion -23. https://doi.org/10. 1002/9780470514269.ch2.

5. Hirano T, Yasukawa K, Harada H, Taga T, Watanabe Y, Matsuda $\mathrm{T}$, et al. Complementary DNA for a novel human interleukin (BSF-2) that induces B lymphocytes to produce immunoglobulin. Nature. 1986;324(6092):73-6. https://doi.org/10.1038/324073a0.

6. Tanaka T, Kishimoto T. The biology and medical implications of interleukin-6. Cancer Immunol Res. 2014;2(4):288-94. https:// doi.org/10.1158/2326-6066.CIR-14-0022.

7. Hunter CA, Jones SA. IL-6 as a keystone cytokine in health and disease. Nat Immunol. 2015;16(5):448-57. https://doi.org/10. 1038/ni.3153.

8. Uciechowski P, Dempke WCM. Interleukin-6: a masterplayer in the cytokine network. Oncology. 2020;98(3):131-7. https://doi. org/10.1159/000505099.

9. Mihara M, Hashizume M, Yoshida H, Suzuki M, Shiina M. IL-6/ IL-6 receptor system and its role in physiological and pathological conditions. Clin Sci (Lond). 2012;122(4):143-59. https://doi.org/ 10.1042/CS20110340.

10. Kang S, Tanaka T, Kishimoto T. Therapeutic uses of antiinterleukin-6 receptor antibody. Int Immunol. 2015;27(1):21-9. https://doi.org/10.1093/intimm/dxu081.

11. Garbers C, Aparicio-Siegmund S, Rose-John S. The IL-6/gp130/ STAT3 signaling axis: recent advances towards specific inhibition. Curr Opin Immunol. 2015;34:75-82. https://doi.org/10. 1016/j.coi.2015.02.008.

12. Scheller J, Chalaris A, Schmidt-Arras D, Rose-John S. The proand anti-inflammatory properties of the cytokine interleukin-6. Biochim Biophys Acta. 2011;1813(5):878-88. https://doi.org/10. 1016/j.bbamcr.2011.01.034.

13. Collaboration IRGCERF, Sarwar N, Butterworth AS, Freitag DF, Gregson J, Willeit P, et al. Interleukin-6 receptor pathways in coronary heart disease: a collaborative meta-analysis of 82 studies. Lancet. 2012;379(9822):1205-13. https://doi.org/10.1016/S01406736(11)61931-4.

14. Kraakman MJ, Kammoun HL, Allen TL, Deswaerte V, Henstridge DC, Estevez E, et al. Blocking IL-6 trans-signaling prevents high-fat diet-induced adipose tissue macrophage recruitment but does not improve insulin resistance. Cell Metab. 2015;21(3):403-16. https://doi.org/10.1016/j.cmet.2015.02.006.

15. Wu YY, Hsu JL, Wang HC, Wu SJ, Hong CJ, Cheng IH. Alterations of the neuroinflammatory markers IL-6 and TRAIL in Alzheimer's disease. Dement Geriatr Cogn Dis Extra. 2015;5(3):424-34. https://doi.org/10.1159/000439214.

16. Tanaka T, Narazaki M, Kishimoto T. IL-6 in inflammation, immunity, and disease. Cold Spring Harb Perspect Biol. 2014;6(10): a016295. https://doi.org/10.1101/cshperspect.a016295.

17. Mosharmovahed B, Fatahi Y, Mohebbi B, Ghorbanian SA, Assadiasl S. Tocilizumab in transplantation. Eur J Clin Pharmacol. 2020;76(6):765-73. https://doi.org/10.1007/s00228020-02864-6.

18. Schett G. Physiological effects of modulating the interleukin-6 axis. Rheumatology (Oxford). 2018;57(suppl_2):ii43-50. https:// doi.org/10.1093/rheumatology/kex513.

19. Rose-John S, Neurath MF. IL-6 trans-signaling: the heat is on. Immunity. 2004;20(1):2-4. https://doi.org/10.1016/s10747613(04)00003-2.

20. Huynh J, Chand A, Gough D, Ernst M. Therapeutically exploiting STAT3 activity in cancer - using tissue repair as a road map. Nat 
Rev Cancer. 2019;19(2):82-96. https://doi.org/10.1038/s41568018-0090-8.

21. Chakraborty D, Sumova B, Mallano T, Chen CW, Distler A, Bergmann C, et al. Activation of STAT3 integrates common profibrotic pathways to promote fibroblast activation and tissue fibrosis. Nat Commun. 2017;8(1):1130. https://doi.org/10.1038/ s41467-017-01236-6.

22. Jarnicki A, Putoczki T, Ernst M. Stat3: linking inflammation to epithelial cancer-more than a "gut" feeling? Cell Div. 2010;5:14. https://doi.org/10.1186/1747-1028-5-14.

23. Rose-John S, Winthrop K, Calabrese L. The role of IL-6 in host defence against infections: immunobiology and clinical implications. Nat Rev Rheumatol. 2017;13(7):399-409. https://doi.org/ 10.1038/nrrheum.2017.83.

24. Horiuchi S, Koyanagi Y, Zhou Y, Miyamoto H, Tanaka Y, Waki M, et al. Soluble interleukin-6 receptors released from T cell or granulocyte/macrophage cell lines and human peripheral blood mononuclear cells are generated through an alternative splicing mechanism. Eur J Immunol. 1994;24(8):1945-8. https://doi.org/ 10.1002/eji.1830240837.

25. Lust JA, Donovan KA, Kline MP, Greipp PR, Kyle RA, Maihle NJ. Isolation of an mRNA encoding a soluble form of the human interleukin-6 receptor. Cytokine. 1992;4(2):96-100. https://doi. org/10.1016/1043-4666(92)90043-q.

26. Mullberg J, Oberthur W, Lottspeich F, Mehl E, Dittrich E, Graeve L, et al. The soluble human IL-6 receptor. Mutational characterization of the proteolytic cleavage site. J Immunol. 1994;152(10): 4958-68.

27. Nishimoto N, Kishimoto T. Interleukin 6: from bench to bedside. Nat Clin Pract Rheumatol. 2006;2(11):619-26. https://doi.org/10. 1038/ncprheum0338.

28. Jordan SC, Ammerman N, Choi J, Kumar S, Huang E, Toyoda M, et al. Interleukin-6: an important mediator of allograft injury. Transplantation. 2020;104(12):2497-506. https://doi.org/10. 1097/TP.0000000000003249.

29. Kishimoto T, Akira S, Narazaki M, Taga T. Interleukin-6 family of cytokines and gp130. Blood. 1995;86(4):1243-54.

30.• Heink S, Yogev N, Garbers C, Herwerth M, Aly L, Gasperi C, et al. Trans-presentation of IL- 6 by dendritic cells is required for the priming of pathogenic TH17 cells. Nat Immunol. 2017;18(1): 74-85. https://doi.org/10.1038/ni.3632 First publication to describe trans-presentation as a mechanism of IL-6 signaling, providing an additional target for therapeutic intervention.

31. Watts RP, Thom O, Fraser JF. Inflammatory signalling associated with brain dead organ donation: from brain injury to brain stem death and posttransplant ischaemia reperfusion injury. J Transp Secur. 2013;2013:521369-19. https://doi.org/10.1155/2013/ 521369.

32. Kupiec-Weglinski JW. Tolerance induction. Curr Opin Organ Transplant. 2008;13(4):331-2. https://doi.org/10.1097/MOT. 0b013e3283069d87.

33. Jurewicz M, Takakura A, Augello A, Movahedi Naini S, Ichimura $\mathrm{T}$, Zandi-Nejad K, et al. Ischemic injury enhances dendritic cell immunogenicity via TLR4 and NF-kappa B activation. J Immunol. 2010;184(6):2939-48. https://doi.org/10.4049/ jimmunol.0901889.

34. Jurewicz M, Ueno T, Azzi J, Tanaka K, Murayama T, Yang S, et al. Donor antioxidant strategy prolongs cardiac allograft survival by attenuating tissue dendritic cell immunogenicity(dagger). Am J Transplant. 2011;11(2):348-55. https://doi.org/10.1111/j. 1600-6143.2010.03360.x.

35. Romano M, Sironi M, Toniatti C, Polentarutti N, Fruscella P, Ghezzi P, et al. Role of IL-6 and its soluble receptor in induction of chemokines and leukocyte recruitment. Immunity. 1997;6(3): 315-25. https://doi.org/10.1016/s1074-7613(00)80334-9.
36. Raasveld MH, Weening JJ, Kerst JM, Surachno S, ten Berge RJ. Local production of interleukin-6 during acute rejection in human renal allografts. Nephrol Dial Transplant. 1993;8(1):75-8. https:// doi.org/10.1093/oxfordjournals.ndt.a092278.

37. Waiser J, Budde K, Katalinic A, Kuerzdorfer M, Riess R, Neumayer HH. Interleukin-6 expression after renal transplantation. Nephrol Dial Transplant. 1997;12(4):753-9. https://doi.org/ 10.1093/ndt/12.4.753.

38. Uehara M, Solhjou Z, Banouni N, Kasinath V, Xiaqun Y, Dai L, et al. Ischemia augments alloimmune injury through IL-6-driven CD4(+) alloreactivity. Sci Rep. 2018;8(1):2461. https://doi.org/ 10.1038/s41598-018-20858-4.

39. Rochman I, Paul WE, Ben-Sasson SZ. IL-6 increases primed cell expansion and survival. J Immunol. 2005;174(8):4761-7. https:// doi.org/10.4049/jimmunol.174.8.4761.

40. Bettelli E, Carrier Y, Gao W, Korn T, Strom TB, Oukka M, et al. Reciprocal developmental pathways for the generation of pathogenic effector TH17 and regulatory T cells. Nature. 2006;441(7090):235-8. https://doi.org/10.1038/nature04753.

41. Dong C. Diversification of T-helper-cell lineages: finding the family root of IL-17-producing cells. Nat Rev Immunol. 2006;6(4): 329-33. https://doi.org/10.1038/nri1807.

42. Korn T, Bettelli E, Oukka M, Kuchroo VK. IL-17 and Th17 Cells. Annu Rev Immunol. 2009;27:485-517. https://doi.org/10.1146/ annurev.immunol.021908.132710.

43. Fujimoto M, Serada S, Mihara M, Uchiyama Y, Yoshida H, Koike $\mathrm{N}$, et al. Interleukin- 6 blockade suppresses autoimmune arthritis in mice by the inhibition of inflammatory Th17 responses. Arthritis Rheum. 2008;58(12):3710-9. https://doi.org/10.1002/art.24126.

44. Serada S, Fujimoto M, Mihara M, Koike N, Ohsugi Y, Nomura S, et al. IL-6 blockade inhibits the induction of myelin antigenspecific Th17 cells and Th1 cells in experimental autoimmune encephalomyelitis. Proc Natl Acad Sci U S A. 2008;105(26): 9041-6. https://doi.org/10.1073/pnas.0802218105.

45. Mihara M, Ohsugi Y, Kishimoto T. Evidence for the role of Th17 cell inhibition in the prevention of autoimmune diseases by antiinterleukin-6 receptor antibody. Biofactors. 2009;35(1):47-51. https://doi.org/10.1002/biof.9.

46. Van Aelst LN, Summer G, Li S, Gupta SK, Heggermont W, De Vusser K, et al. RNA profiling in human and murine transplanted hearts: identification and validation of therapeutic targets for acute cardiac and renal allograft rejection. Am J Transplant. 2016;16(1): 99-110. https://doi.org/10.1111/ajt.13421.

47. Yang XO, Nurieva R, Martinez GJ, Kang HS, Chung Y, Pappu $\mathrm{BP}$, et al. Molecular antagonism and plasticity of regulatory and inflammatory T cell programs. Immunity. 2008;29(1):44-56. https://doi.org/10.1016/j.immuni.2008.05.007.

48. Thiolat A, Semerano L, Pers YM, Biton J, Lemeiter D, Portales P, et al. Interleukin-6 receptor blockade enhances CD39+ regulatory $\mathrm{T}$ cell development in rheumatoid arthritis and in experimental arthritis. Arthritis Rheum. 2014;66(2):273-83. https://doi.org/10. 1002/art.38246.

49. Fogal B, Yi T, Wang C, Rao DA, Lebastchi A, Kulkarni S, et al. Neutralizing IL-6 reduces human arterial allograft rejection by allowing emergence of CD161+CD4+ regulatory $\mathrm{T}$ cells. J Immunol. 2011;187(12):6268-80. https://doi.org/10.4049/ jimmunol.1003774.

50. Campbell DJ, Koch MA. Phenotypical and functional specialization of FOXP3 + regulatory T cells. Nat Rev Immunol. 2011;11(2):119-30. https://doi.org/10.1038/nri2916.

51. Li XC, Turka LA. An update on regulatory T cells in transplant tolerance and rejection. Nat Rev Nephrol. 2010;6(10):577-83. https://doi.org/10.1038/nrneph.2010.101.

52. von Rossum A, Rey K, Enns W, Manku S, Cheema R, MacEwan GE, et al. Graft-derived IL- 6 amplifies proliferation and survival of effector $\mathrm{T}$ cells that drive alloimmune-mediated vascular 
rejection. Transplantation. 2016;100(11):2332-41. https://doi.org/ 10.1097/TP.0000000000001227.

53. Ma CS, Deenick EK, Batten M, Tangye SG. The origins, function, and regulation of $\mathrm{T}$ follicular helper cells. J Exp Med. 2012;209(7):1241-53. https://doi.org/10.1084/jem.20120994.

54. Diehl SA, Schmidlin H, Nagasawa M, Blom B, Spits H. IL-6 triggers IL-21 production by human CD4+ $\mathrm{T}$ cells to drive STAT3-dependent plasma cell differentiation in B cells. Immunol Cell Biol. 2012;90(8):802-11. https://doi.org/10.1038/ icb.2012.17.

55. Kawano M, Hirano T, Matsuda T, Taga T, Horii Y, Iwato K, et al. Autocrine generation and requirement of BSF-2/IL-6 for human multiple myelomas. Nature. 1988;332(6159):83-5. https://doi. org/10.1038/332083a0.

56. Suematsu S, Matsusaka T, Matsuda T, Ohno S, Miyazaki J, Yamamura K, et al. Generation of plasmacytomas with the chromosomal translocation $\mathrm{t}(12 ; 15)$ in interleukin 6 transgenic mice. Proc Natl Acad Sci U S A. 1992;89(1):232-5. https://doi.org/10. 1073/pnas.89.1.232.

57. Wu G, Chai N, Kim I, Klein AS, Jordan SC. Monoclonal antiinterleukin- 6 receptor antibody attenuates donor-specific antibody responses in a mouse model of allosensitization. Transpl Immunol. 2013;28(2-3):138-43. https://doi.org/10.1016/j.trim. 2013.03.003.

58. Nishimoto N, Terao K, Mima T, Nakahara H, Takagi N, Kakehi $\mathrm{T}$. Mechanisms and pathologic significances in increase in serum interleukin-6 (IL-6) and soluble IL-6 receptor after administration of an anti-IL-6 receptor antibody, tocilizumab, in patients with rheumatoid arthritis and Castleman disease. Blood. 2008;112(10):3959-64. https://doi.org/10.1182/blood-2008-05155846.

59.• Vo AA, Choi J, Kim I, Louie S, Cisneros K, Kahwaji J, et al. A Phase I/II Trial of the Interleukin-6 Receptor-Specific Humanized Monoclonal (Tocilizumab) + Intravenous Immunoglobulin in Difficult to Desensitize Patients. Transplantation. 2015;99(11): 2356-63. https://doi.org/10.1097/TP.0000000000000741 First publication to report clinical application of IL-6 signaling inhibition in solid organ transplantation. This paper describes successful use of tocilizumab for desensitization prior to kidney transplantation.

60. Kishimoto T. IL-6: from its discovery to clinical applications. Int Immunol. 2010;22(5):347-52. https://doi.org/10.1093/intimm/ dxq030.

61. Zhang ZX, Huang X, Jiang J, Lian D, Min WP, Liu W, et al Natural killer cells play a critical role in cardiac allograft vasculopathy in an interleukin-6-dependent manner. Transplantation. 2014;98(10):1029-39. https://doi.org/10.1097/TP. 0000000000000405

62. Haruta H, Ohguro N, Fujimoto M, Hohki S, Terabe F, Serada S, et al. Blockade of interleukin-6 signaling suppresses not only th 17 but also interphotoreceptor retinoid binding protein-specific Th1 by promoting regulatory $\mathrm{T}$ cells in experimental autoimmune uveoretinitis. Invest Ophthalmol Vis Sci. 2011;52(6):3264-71. https://doi.org/10.1167/iovs.10-6272.

63. Korn T, Mitsdoerffer M, Croxford AL, Awasthi A, Dardalhon VA, Galileos G, et al. IL-6 controls Th17 immunity in vivo by inhibiting the conversion of conventional $\mathrm{T}$ cells into Foxp3+ regulatory T cells. Proc Natl Acad Sci U S A. 2008;105(47): 18460-5. https://doi.org/10.1073/pnas.0809850105.

64. Emilie D, Liozon E, Crevon MC, Lavignac C, Portier A, Liozon F, et al. Production of interleukin 6 by granulomas of giant cell arteritis. Hum Immunol. 1994;39(1):17-24. https://doi.org/10.1016/ 0198-8859(94)90096-5.

65. Shen H, Goldstein DR. IL-6 and TNF-alpha synergistically inhibit allograft acceptance. J Am Soc Nephrol. 2009;20(5):1032-40. https://doi.org/10.1681/ASN.2008070778.
66. Kim I, Wu G, Chai NN, Klein AS, Jordan S. Anti-interleukin 6 receptor antibodies attenuate antibody recall responses in a mouse model of allosensitization. Transplantation. 2014;98(12):126270. https://doi.org/10.1097/TP.0000000000000437.

67. Liang Y, Christopher K, Finn PW, Colson YL, Perkins DL. Graft produced interleukin- 6 functions as a danger signal and promotes rejection after transplantation. Transplantation. 2007;84(6):771-7. https://doi.org/10.1097/01.tp.0000281384.24333.0b.

68.• Wheeler DS, Misumi K, Walker NM, Vittal R, Combs MP, Aoki $\mathrm{Y}$, et al. Interleukin 6 trans-signaling is a critical driver of lung allograft fibrosis. Am J Transplant. 2020. https://doi.org/10.1111/ ajt.16417 Important study describing the role and potential mechanism by which IL-6 signaling promotes development of chronic lung allograft dysfunction.

69. Booth AJ, Bishop DK. TGF-beta, IL-6, IL-17 and CTGF direct multiple pathologies of chronic cardiac allograft rejection. Immunotherapy. 2010;2(4):511-20. https://doi.org/10.2217/imt. 10.33 .

70. Diaz JA, Booth AJ, Lu G, Wood SC, Pinsky DJ, Bishop DK. Critical role for IL-6 in hypertrophy and fibrosis in chronic cardiac allograft rejection. Am J Transplant. 2009;9(8):1773-83. https:// doi.org/10.1111/j.1600-6143.2009.02706.x.

71. Booth AJ, Grabauskiene S, Wood SC, Lu G, Burrell BE, Bishop DK. IL-6 promotes cardiac graft rejection mediated by CD4+ cells. J Immunol. 2011;187(11):5764-71. https://doi.org/10. 4049/jimmunol.1100766.

72. Zhao X, Boenisch O, Yeung M, Mfarrej B, Yang S, Turka LA, et al. Critical role of proinflammatory cytokine IL-6 in allograft rejection and tolerance. Am J Transplant. 2012;12(1):90-101. https://doi.org/10.1111/j.1600-6143.2011.03770.x.

73. Kimura N, Itoh S, Nakae S, Axtell RC, Velotta JB, Bos EJ, et al. Interleukin-16 deficiency suppresses the development of chronic rejection in murine cardiac transplantation model. J Heart Lung Transplant. 2011;30(12):1409-17. https://doi.org/10.1016/j. healun.2011.08.017.

74. Iida S, Omoto K, Kanemitsu I, Setoguchi K, Ishida H, Tanabe K, et al. Interleukin-6 receptor signaling disruption prevents cardiac allograft deterioration in mice. Exp Clin Transplant. 2012;10(4): 375-85. https://doi.org/10.6002/ect.2011.0159.

75. Booth AJ, Csencsits-Smith K, Wood SC, Lu G, Lipson KE, Bishop DK. Connective tissue growth factor promotes fibrosis downstream of TGFbeta and IL- 6 in chronic cardiac allograft rejection. Am J Transplant. 2010;10(2):220-30. https://doi.org/ 10.1111/j.1600-6143.2009.02826.x.

76. Wang H, Guan Q, Lan Z, Li S, Ge W, Chen H, et al. Prolonged renal allograft survival by donor interleukin-6 deficiency: association with decreased alloantibodies and increased intragraft $\mathrm{T}$ regulatory cells. Am J Physiol Ren Physiol. 2012;302(2):F276-83. https://doi.org/10.1152/ajprenal.00258.2011.

77. Riella LV, Yang J, Chock S, Safa K, Magee CN, Vanguri V, et al. Jagged2-signaling promotes IL-6-dependent transplant rejection. Eur J Immunol. 2013;43(6):1449-58. https://doi.org/10.1002/eji. 201243151.

78. Granofszky N, Farkas AM, Muckenhuber M, Mahr B, Unger L, Maschke S, et al. Anti-interleukin-6 promotes allogeneic bone marrow engraftment and prolonged graft survival in an irradiation-free murine transplant model. Front Immunol. 2017;8:821. https://doi.org/10.3389/fimmu.2017.00821.

79. Lei J, He F, Wu M, Zheng X, Chen X, Chen Z. Administration of anti-interleukin-6 monoclonal antibody prolongs cardiac allograft survival. Transpl Int. 2010;23(12):1271-81. https://doi.org/10. 1111/j.1432-2277.2010.01125.x.

80. Casiraghi F, Ruggenenti P, Noris M, Locatelli G, Perico N, Perna A, et al. Sequential monitoring of urine-soluble interleukin 2 receptor and interleukin 6 predicts acute rejection of human renal allografts before clinical or laboratory signs of renal dysfunction. 
Transplantation. 1997;63(10):1508-14. https://doi.org/10.1097/ 00007890-199705270-00023.

81. Smith SD, Wheeler MA, Lorber MI, Weiss RM. Temporal changes of cytokines and nitric oxide products in urine from renal transplant patients. Kidney Int. 2000;58(2):829-37. https://doi.org/10. 1046/j.1523-1755.2000.00232.x.

82. Abdallah AN, Billes MA, Attia Y, Doutremepuich C, Cassaigne A, Iron A. Evaluation of plasma levels of tumour necrosis factor alpha and interleukin- 6 as rejection markers in a cohort of 142 heart-grafted patients followed by endomyocardial biopsy. Eur Heart J. 1997;18(6):1024-9. https://doi.org/10.1093/ oxfordjournals.eurheartj.a015361.

83. Perez-Villa F, Benito B, Llancaqueo M, Cuppoletti A, Roig E. Elevated levels of serum interleukin- 6 are associated with low grade cellular rejection in patients with heart transplantation. Transplant Proc. 2006;38(9):3012-5. https://doi.org/10.1016/j. transproceed.2006.08.113.

84. Verleden SE, Martens A, Ordies S, Neyrinck AP, Van Raemdonck DE, Verleden GM, et al. Immediate post-operative broncho-alveolar lavage IL-6 and IL- 8 are associated with early outcomes after lung transplantation. Clin Transpl. 2018;32(4): e13219. https://doi.org/10.1111/ctr.13219.

85. Iacono A, Dauber J, Keenan R, Spichty K, Cai J, Grgurich W, et al. Interleukin 6 and interferon-gamma gene expression in lung transplant recipients with refractory acute cellular rejection: implications for monitoring and inhibition by treatment with aerosolized cyclosporine. Transplantation. 1997;64(2):263-9. https://doi. org/10.1097/00007890-199707270-00015.

86. Yoshida Y, Iwaki Y, Pham S, Dauber JH, Yousem SA, Zeevi A, et al. Benefits of posttransplantation monitoring of interleukin 6 in lung transplantation. Ann Thorac Surg. 1993;55(1):89-93. https:// doi.org/10.1016/0003-4975(93)90479-2.

87. Wang S, Jiang J, Guan Q, Lan Z, Wang H, Nguan CY, et al. Reduction of Foxp3-expressing regulatory $\mathrm{T}$ cell infiltrates during the progression of renal allograft rejection in a mouse model. Transpl Immunol. 2008;19(2):93-102. https://doi.org/10.1016/j. trim.2008.03.004.

88. Tse GH, Johnston CJ, Kluth D, Gray M, Gray D, Hughes J, et al. Intrarenal B cell cytokines promote transplant fibrosis and tubular atrophy. Am J Transplant. 2015;15(12):3067-80. https://doi.org/ 10.1111/ajt.13393.

89. Van Oers MH, Van der Heyden AA, Aarden LA. Interleukin 6 (IL-6) in serum and urine of renal transplant recipients. Clin Exp Immunol. 1988;71(2):314-9.

90. Krams SM, Falco DA, Villanueva JC, Rabkin J, Tomlanovich SJ, Vincenti $\mathrm{F}$, et al. Cytokine and $\mathrm{T}$ cell receptor gene expression at the site of allograft rejection. Transplantation. 1992;53(1):151-6. https://doi.org/10.1097/00007890-199201000-00031.

91. Kawai T, Sachs DH, Sykes M, Cosimi AB, Immune TN. HLAmismatched renal transplantation without maintenance immunosuppression. N Engl J Med. 2013;368(19):1850-2. https://doi.org/ 10.1056/NEJMc1213779.

92. Schmidt-Arras D, Rose-John S. IL-6 pathway in the liver: from physiopathology to therapy. J Hepatol. 2016;64(6):1403-15. https://doi.org/10.1016/j.jhep.2016.02.004.

93. Cressman DE, Greenbaum LE, DeAngelis RA, Ciliberto G, Furth EE, Poli V, et al. Liver failure and defective hepatocyte regeneration in interleukin-6-deficient mice. Science. 1996;274(5291): 1379-83. https://doi.org/10.1126/science.274.5291.1379.

94. Galun E, Axelrod JH. The role of cytokines in liver failure and regeneration: potential new molecular therapies. Biochim Biophys Acta. 2002;1592(3):345-58. https://doi.org/10.1016/s01674889(02)00326-9.

95. Gorczynski RM, Adams RB, Levy GA, Chung SW. Correlation of peripheral blood lymphocyte and intragraft cytokine mRNA expression with rejection in orthotopic liver transplantation.
Surgery. 1996;120(3):496-502. https://doi.org/10.1016/s00396060(96)80069-9.

96. Yao J, Feng XW, Yu XB, Xie HY, Zhu LX, Yang Z, et al. Recipient IL-6-572C/G genotype is associated with reduced incidence of acute rejection following liver transplantation. J Int Med Res. 2013;41(2):356-64. https://doi.org/10.1177/ 0300060513477264 .

97. Kita Y, Iwaki Y, Demetris AJ, Starzl TE. Evaluation of sequential serum interleukin-6 levels in liver allograft recipients. Transplantation. 1994;57(7):1037-41. https://doi.org/10.1097/ 00007890-199404150-00009.

98. Ohzato H, Monden M, Yoshizaki K, Gotoh M, Kanai T, Umeshita $\mathrm{K}$, et al. Serum interleukin-6 levels as an indicator of acute rejection after liver transplantation in cynomologous monkeys. Surg Today. 1993;23(6):521-7. https://doi.org/10.1007/BF00730628.

99. Karimi MH, Daneshmandi S, Pourfathollah AA, Geramizadeh B, Malekhosseini SA, Nikeghbalian S, et al. Association of IL-6 promoter and IFN-gamma gene polymorphisms with acute rejection of liver transplantation. Mol Biol Rep. 2011;38(7):4437-43. https://doi.org/10.1007/s11033-010-0572-6.

100. Selzner N, Selzner M, Tian Y, Kadry Z, Clavien PA. Cold ischemia decreases liver regeneration after partial liver transplantation in the rat: a TNF-alpha/IL-6-dependent mechanism. Hepatology. 2002;36(4 Pt 1):812-8. https://doi.org/10.1053/jhep.2002.35535.

101. Sun Z, Klein AS, Radaeva S, Hong F, El-Assal O, Pan HN, et al. In vitro interleukin- 6 treatment prevents mortality associated with fatty liver transplants in rats. Gastroenterology. 2003;125(1):20215. https://doi.org/10.1016/s0016-5085(03)00696-6.

102. Deng MC, Plenz G, Labarrere C, Marboe C, Baba HA, Erre M, et al. The role of IL6 cytokines in acute cardiac allograft rejection. Transpl Immunol. 2002;9(2-4):115-20. https://doi.org/10.1016/ s0966-3274(02)00004-7.

103. Zhao XM, Frist WH, Yeoh TK, Miller GG. Expression of cytokine genes in human cardiac allografts: correlation of IL- 6 and transforming growth factor-beta (TGF-beta) with histological rejection. Clin Exp Immunol. 1993;93(3):448-51. https://doi.org/ 10.1111/j.1365-2249.1993.tb08199.x.

104. Baan CC, Niesters HG, Balk AH, Mochtar B, Zondervan PE, Weimar W. The intragraft cytokine mRNA pattern reflects the efficacy of steroid antirejection therapy. J Heart Lung Transplant. 1996;15(12):1184-93.

105. Chen L, Ahmed E, Wang T, Wang Y, Ochando J, Chong AS, et al. TLR signals promote IL-6/IL-17-dependent transplant rejection. J Immunol. 2009;182(10):6217-25. https://doi.org/10.4049/ jimmunol.0803842.

106. Rolfe MW, Kunkel S, Lincoln P, Deeb M, Lupinetti F, Strieter R. Lung allograft rejection: role of tumor necrosis factor-alpha and interleukin-6. Chest. 1993;103(2 Suppl):133S. https://doi.org/10. 1378/chest.103.2 supplement.133s.

107. Tonsho M, Lee S, Aoyama A, Boskovic S, Nadazdin O, Capetta $\mathrm{K}$, et al. Tolerance of lung allografts achieved in nonhuman primates via mixed hematopoietic chimerism. Am J Transplant. 2015;15(8):2231-9. https://doi.org/10.1111/ajt.13274.

108. Kaneda H, Waddell TK, de Perrot M, Bai XH, Gutierrez C, Arenovich T, et al. Pre-implantation multiple cytokine mRNA expression analysis of donor lung grafts predicts survival after lung transplantation in humans. Am J Transplant. 2006;6(3): 544-51. https://doi.org/10.1111/j.1600-6143.2005.01204.x.

109. Sage AT, Besant JD, Mahmoudian L, Poudineh M, Bai X, Zamel $\mathrm{R}$, et al. Fractal circuit sensors enable rapid quantification of biomarkers for donor lung assessment for transplantation. Sci Adv. 2015;1(7):e1500417. https://doi.org/10.1126/sciadv.1500417.

110. Whitehead BF, Stoehr C, Wu CJ, Patterson G, Burchard EG, Theodore J, et al. Cytokine gene expression in human lung transplant recipients. Transplantation. 1993;56(4):956-61. https://doi. org/10.1097/00007890-199310000-00034. 
111. Rizzo M, SivaSai KS, Smith MA, Trulock EP, Lynch JP, Patterson GA, et al. Increased expression of inflammatory cytokines and adhesion molecules by alveolar macrophages of human lung allograft recipients with acute rejection: decline with resolution of rejection. J Heart Lung Transplant. 2000;19(9):858-65. https://doi.org/10.1016/s1053-2498(00)00165-0.

112. Kang S, Tanaka T, Narazaki M, Kishimoto T. Targeting interleukin-6 signaling in clinic. Immunity. 2019;50(4):100723. https://doi.org/10.1016/j.immuni.2019.03.026.

113. Tanaka T, Narazaki M, Kishimoto T. Therapeutic targeting of the interleukin-6 receptor. Annu Rev Pharmacol Toxicol. 2012;52: 199-219. https://doi.org/10.1146/annurev-pharmtox-010611134715.

114. Gupta S, Wang W, Hayek SS, Chan L, Mathews KS, Melamed ML, et al. Association between early treatment with tocilizumab and mortality among critically Ill patients with COVID-19. JAMA Intern Med. 2021;181(1):41-51. https://doi.org/10.1001/ jamainternmed.2020.6252.

115.• Choi J, Aubert O, Vo A, Loupy A, Haas M, Puliyanda D, et al. Assessment of tocilizumab (anti-interleukin-6 receptor monoclonal) as a potential treatment for chronic antibody-mediated rejection and transplant glomerulopathy in HLA-sensitized renal allograft recipients. Am J Transplant. 2017;17(9):2381-9. https://doi. org/10.1111/ajt.14228 First report on successful use of IL-6 signaling inhibition with tocilizumab for treatment of chronic AMR in kidney transplant recipients who failed standard of care treatment.

116. Lavacca A, Presta R, Gai C, Mella A, Gallo E, Camussi G, et al. Early effects of first-line treatment with anti-interleukin- 6 receptor antibody tocilizumab for chronic active antibody-mediated rejection in kidney transplantation. Clin Transpl. 2020;34(8):e13908. https://doi.org/10.1111/ctr.13908.

117. Pottebaum AA, Venkatachalam K, Liu C, Brennan DC, Murad H, Malone AF, et al. Efficacy and safety of tocilizumab in the treatment of acute active antibody-mediated rejection in kidney transplant recipients. Transplant Direct. 2020;6(4):e543. https://doi. org/10.1097/TXD.0000000000000988.

118. Chandran S, Leung J, Hu C, Laszik ZG, Tang Q, Vincenti FG. Interleukin-6 blockade with tocilizumab increases Tregs and reduces $\mathrm{T}$ effector cytokines in renal graft inflammation: A randomized controlled trial. Am J Transplant. 2020. https://doi.org/10. 1111/ajt.16459 This paper describes results from a randomized-controlled trial investigating use of tocilizumab for patients with subclinical renal allograft inflammation. The study demonstrated efficacy of tocilizumab in regulating the T-cell alloimmune response.

119. Targeting Inflammation and Alloimmunity in Heart Transplant Recipients with Tocilizumab (ALL IN). Available from: https:// www.clinicaltrials.gov/show/NCT03644667.

120. Vo A, Ammerman N, Huang E, Toyoda M, Ge S, Peng A, et al. Clazakizumab® (Anti-IL-6) for desensitization of highly-HLA sensitized patients awaiting kidney transplant (NCT03380962) [abstract]. Transplantation. 2020;104(S3):S104-S5. https://doi. org/10.1097/01.tp.0000698796.63079.e4.

121. Jordan S, Ammerman N, Toyoda M, Ge S, Huang E, Peng A, et al. Clazakizumab (anti-IL-6-monoclonal) treatment of patients with chronic and active antibody-mediated rejection post-kidney transplantation (NCT03380377) [abstract]. Transplantation. 2020;104(S3):S67-S8. https://doi.org/10.1097/01.tp. 0000698592.29821.e5.

122. Eskandary F, Durr M, Budde K, Doberer K, Reindl-Schwaighofer $\mathrm{R}$, Waiser J, et al. Clazakizumab in late antibody-mediated rejection: study protocol of a randomized controlled pilot trial. Trials. 2019;20(1):37. https://doi.org/10.1186/s13063-018-3158-6 This article provides scientific rationale and protocol details for the first multicenter, randomized-controlled trial on use of clazakizumab for kidney transplant recipients with cAMR.

123. Doberer K, Duerr M, Halloran PF, Eskandary F, Budde K, Regele $\mathrm{H}$, et al. A randomized clinical trial of anti-IL-6 antibody clazakizumab in late antibody-mediated kidney transplant rejection [abstract]. J Am Soc Nephrol. 2020;32:708-22. https://doi. org/10.1681/ASN.2020071106.

124. Clazakizumab for the Treatment of Chronic Active Antibody Mediated Rejection in Kidney Transplant Recipients (IMAGINE) Available from: https://www.clinicaltrials.gov/ show/NCT03744910.

125. Massat M, Congy-Jolivet N, Hebral AL, Esposito L, Marion O, Delas A, et al. Do anti-IL-6R blockers have a beneficial effect in the treatment of antibody-mediated rejection resistant to standard therapy after kidney transplantation? Am J Transplant. 2020;21: 1641-9. https://doi.org/10.1111/ajt.16391.

126. Sethi S, Peng A, Najjar R, Vo A, Jordan SC, Huang E. Infectious complications in tocilizumab-treated kidney transplant recipients. Transplantation. 2021. https://doi.org/10.1097/TP. 0000000000003512 Publish Ahead of Print.

127.• Weinblatt ME, Mease P, Mysler E, Takeuchi T, Drescher E, Berman A, et al. The efficacy and safety of subcutaneous clazakizumab in patients with moderate-to-severe rheumatoid arthritis and an inadequate response to methotrexate: results from a multinational, phase IIb, randomized, double-blind, placebo/active-controlled, dose-ranging study. Arthritis Rheum. 2015;67(10):2591-600. https://doi.org/10.1002/art.39249.

128. Jordan S, Ge S, Ammerman N, Toyoda M, Huang E, Peng A, et al. Clazakizumab (anti-IL-6) induces FoxP3+ Tregs in highly HLA sensitized patients receiving HLAi kidney transplantation (NCT03380962) [abstract]. Transplantation. 2020;104(S3):S105. https://doi.org/10.1097/01.tp.0000698800.17823.68.

129. Jordan SC, Ammerman N, Choi J, Huang E, Peng A, Sethi S, et al. The role of novel therapeutic approaches for prevention of allosensitization and antibody-mediated rejection. Am J Transplant. 2020;20(Suppl 4):42-56. https://doi.org/10.1111/ajt. 15913 This review includes interval results from a clinical trial investigating use of clazakizumab in kidney transplant recipients with $\mathrm{cAMR}$, with promising initial findings regarding safety and efficacy of the drug.

130. Borski A, Haindl S, Dürr M, Budde K, Schranz S, Eskandary F, et al. Anti-IL-6 antibody clazakizumab in late antibody-mediated rejection-molecular rebound phenomena under IL-6 blockade? [abstract]. Transplantation. 2020;104(S3):S67. https://doi.org/10. 1097/01.tp.0000698588.88678.f6.

Publisher's Note Springer Nature remains neutral with regard to jurisdictional claims in published maps and institutional affiliations. 